\title{
Simulation model comparing the hydroperiod of temporary ponds with different shapes
}

\author{
Alfonso Garmendia ${ }^{1, *}$ and Joan Pedrola-Monfort ${ }^{2}$ \\ ${ }^{1}$ Instituto Agroforestal Mediterráneo. Departamento de Ecosistemas Agroforestales. Universidad Politécnica de \\ Valencia. \\ ${ }^{2}$ Instituto Cavanilles de Biodiversidad y Biología Evolutiva. Universidad de Valencia. joan.pedrola@uv.es \\ * Corresponding author: algarsal@upvnet.upv.es
}

Received: $28 / 2 / 09$

Accepted: 28/6/09

\begin{abstract}
Simulation model comparing the hydroperiod of temporary ponds with different shapes

A model of the water dynamics for shallow, small and temporary Mediterranean ponds has been developed taking into account the annual patterns of rainfall and potential evaporation, pond parameters (pond area, depth and shape) and watershed parameters (watershed area and saturated water content of the soil). This model predicts the amount of water retained in the pond in real time and therefore, when a pond is going to dry out. It is then possible to calculate how much water will remain in the pond after raining or the number of days per year that the pond is going to be dry. Analyses have been performed for different shapes of ponds and sensitivity of the state variables, at different values for the parameters. The most interesting result of our simulations is that the amount of water in the pond (as \% of the total) strongly depends on pond shape and maximum depth and saturated water content of the watershed. Watershed area of the pond will only be important for low intensity rain regimes and for soils with very low saturated water content. Also, the number of days without water (per year) depends on shape and maximum pond depth. Deeper ponds will dry at a slower rate (and therefore have more days with water a year and consequently shorter drought periods) than shallower ones, independently of their area or the total amount of water. A conical pond should have more days with water for the same amount of rain, unless the pond does get totally full in each rainfall episode. Around the Mediterranean Basin, most temporary ponds have a certain degree of artificiality (because of agriculture or farms). Thus, this model could help in controlling the hydroperiod by conveniently modifying shapes and depth of ponds to manage and preserve different species or biotic communities. The simulation model used is freely available from the authors or in: http://personales.upv.es/ algarsal/temporary ponds.zip.
\end{abstract}

Key words: Hydroperiod, Hydrologic model, Temporary Mediterranean ponds, Ephemeral wetlands, Pond shape, Temporary pond restoration.

\section{RESUMEN}

Modelo de simulación para comparar el hidroperiodo de las charcas temporales según su forma

Se ha desarrollado un modelo de dinámica de aguas para charcas pequeñas, someras y temporales teniendo en cuenta los patrones anuales de lluvia y evaporación potencial, parámetros de la charca (área de la charca, profundidad y forma) y parámetros de la cuenca de captación (área de la cuenca y contenido de agua del suelo a saturación). Este modelo predice la cantidad de agua dentro de la charca en tiempo real y consecuentemente cuándo ésta va a secarse. Es entonces posible calcular cuanta agua permanecerá en la charca después de una lluvia o el número de días por año que la charca va a estar seca. Se han llevado a cabo diversos análisis para diferentes formas de charcas así como para comprobar la sensitividad de las variables de estado a diferentes parámetros. Lo más interesante de nuestras simulaciones es que la cantidad de agua dentro de la charca (como \% del total) depende estrechamente de la forma de la charca y la profundidad máxima así como del contenido de captación de saturación de agua en su cuenca de captación. El área de la cuenca de captación de la charca solo será importante para regímenes de lluvia de baja intensidad y para suelos que saturan rápidamente (con muy bajo contenido de agua a saturación). También el número de días sin agua (por año) depende de la forma y de la profundidad máxima de la charca. Las charcas profundas se secarán lentamente (y consecuentemente estarán con agua más días al año y por tanto periodos más cortos de sequía) que las someras, independientemente de su área o de la cantidad total 
de agua. Una charca cónica debera entonces tener más días con agua para las mismas precipitaciones a menos que la charca se llene totalmente en cada episodio lluvioso. Alrededor de la Cuenca Mediterránea, la inmensa mayoría de charcas temporales tienen un cierto grado de artificialidad (debido a la agricultura y ganadería). Así, este modelo podría ayudar a controlar el hidroperiodo a conveniencia modificando la forma y profundidad de las charcas para manejar y preservar las diferentes especies o comunidades bióticas. El modelo de simulación utilizado es posible adquirirlo gratis de los autores o en: http://personales.upv.es/ algarsal/temporary ponds.zip.

Palabras clave: Hidroperiodo, modelo hidrológico, charcas temporales mediterráneas, zonas húmedas efímeras, forma de la charca, restauración de charcas temporales.

\section{INTRODUCTION}

Inevitably, the global population decline of aquatic organisms caused by agriculture intensification is a reality and this is not less apparent than in the decline of amphibian populations (Beja \& Alcazar, 2003, Houlahan et al., 2000). Climate change, too, can have a negative impact upon these organisms as a result of dramatic changes in levels of precipitation. In order to conserve these organisms and to enhance freshwater biodiversity, environmental managers need information and advice on how to manage existing ponds and create new ponds (Williams et al., 2008).

In Mediterranean climate areas, the physiologically stressful transition between inundation during the winter growing season and desiccation during dry summer in shallow, small temporary ponds is the cause for distinctive plant and animal communities (Keeley and Zedler 1998). Understanding hydrologic processes and their dependence on morphology of vernal temporary ponds is a fundamental key to manage biotic introductions and the restoration and creation of new temporary pond ecosystems (Mitsch and Gosselink, 2000).

Some studies based on characterization of hydrologic conditions within vernal temporary ponds demonstrated the critical role of the hydroregime in a variety of ecological processes, including dispersal rates, reproductive success, and life history strategies (Gallagher, 1993; King et al., 1996; Simovich \& Hathaway, 1997; Marcus \& Weeks, 1997; Morey, 1998; Bohonak \& Whiteman, 1999; Snodgrass et al., 1999; Brooks, 2000; Stamati et al., 2008). It also correlates with ecological patterns of species richness and community composition (Crowe et al., 1994; Bliss and Zedler, 1998). These studies usually include correlations with maximum depth, surface area, or short duration observation of hydrologic conditions, but they have a limited ability to describe patterns of intra or inter-annual variability. Similar hydrological models have been made to fit specific goals in particular ponds (Pyke 2004, Zhang et al., 2005) but they did not study the effect of each pond parameter as regards to the final result.

The main aim of this work is to develop a simple water balance model linking weather data (rainfall, potential evapotranspiration) to pond hydroregimes, using the relationships with pond geometry and size and watershed parameters. This model is necessary for testing the sensitivity of the different pond characteristics against the hydroperiod and detecting which of them are the most sensitive. The final goal will be to consider ways in which ponds may be modified or created with a desired hydroperiod.

The model should allow efficient simulation of variations in hydroregime produced by different pond characteristics, but to predict efficiently the hydroregime of real ponds it needs to be calibrated and validated. In order to do this the authors are undertaking this work in ephemeral vernal ponds in Eastern Spain, as well as encouraging other workers to use this approach in their research and management activities.

This model is freely available on http://personales.upv.es/ algarsal/temporary ponds.zip or by contacting the authors. 


\section{MATERIAL AND METHODS}

\section{Water balance dynamic simulation model}

The model is a simple water balance model with a single temporary pond basin as the functional unit of analysis. A basin receives water inputs from direct precipitation and inflow via the saturated watershed, and it loses water through evapotranspiration and overflow events. The groundwater is supposed to be impermeable in this model, but in cases of changes in water volume not accounted for by precipitation and evaporation, it could be used to estimate seepage.

The following mass-balance mathematical equation was used to determine the structure of the dynamic simulation model for daily water budget in the pond:

$$
\frac{d v}{d t}=P_{v}(t)+D(t)-E_{v}(t)-S(t)
$$

where $d v / d t$ is the rate of change in water volume in the temporary pond, if $d v / d t=0$, then input values are equal to output values; $P_{v}(t)$ is daily precipitation over the pond surface; $D(t)$ is daily drainage to the pond from the watershed; $E_{v}(t)$ is daily evapotranspiration on the pond surface; $S(t)$ is Surface overflow when the pond is full, all of them in litres; and $t$ is time (days).

Daily precipitation $P(t)$ and evaporation data $E(t)$, both are in $\mathrm{mm}$, and should be obtained from the closest meteorological station available. For the sensitivity analysis, data for Tortosa were obtained from National Meteorology Institute of Spain.

\section{Watershed}

The parameters used to describe watersheds are: the watershed area $W A\left(\mathrm{~m}^{2}\right)$ and the saturated water content $F C$ measured as the maximum amount of water that the soil can absorb before it starts to overflow $\left(1 / \mathrm{m}^{2}\right)$. Therefore, the maximum amount of water in the soil of the watershed $W_{\max }$ is:

$$
W_{\max }=W A \times F C
$$

The amount of water flowing to the pond from the watershed depends on the humidity of the soil and therefore on the water dynamic in the soil of the watershed area. This dynamic is modelled by:

$$
\begin{aligned}
& \text { If } W>W_{\max } \text {, then } \\
& \qquad \frac{d W}{d t}=P_{w}(t)-E_{w}(t)-D(t)
\end{aligned}
$$

else

$$
\frac{d W}{d t}=P_{w}(t)-E_{w}(t)
$$

where $d W / d t$ is the rate of change in water volume in the soil of the watershed area; $P_{w}(t)$ is daily precipitation over the watershed area; $E_{w}(t)$ is daily evapotranspiration on the watershed surface, both of them also in litres; and $t$ is time.

For the Mediterranean ponds under study, all the water input is from precipitation. Precipitation over the watershed produces an increase of the amount of water in the soil:

$$
P_{w}(t)=P(t) \times W A
$$

Evaporation, on the other hand is the main output process:

$$
E_{w}(t)=W A \times E(t) \times\left(\frac{W(t)}{W_{\max }}\right)
$$

where $W(t) / W_{\max }$ is a correction factor that reflects the fact that water evaporates better when soil is saturated with water $\left(W(t)=W_{\max }\right)$ and worst as the amount of water lessens. Evaporation is zero when all possible water is evaporated and $\mathrm{W}(t)=0$. This equation can be simplified using equation (2) to:

$$
E_{w}(t)=\frac{E(t) \times W(t)}{F C}
$$

Only when $W>W_{\max }$, overflow occurs:

$$
D(t)=W(t)-W_{\max }
$$

\section{Pond parameters}

The parameters used to describe the pond are: $M A$, maximum area $\left(\mathrm{m}^{2}\right) ; M D$, maximum depth 
a)

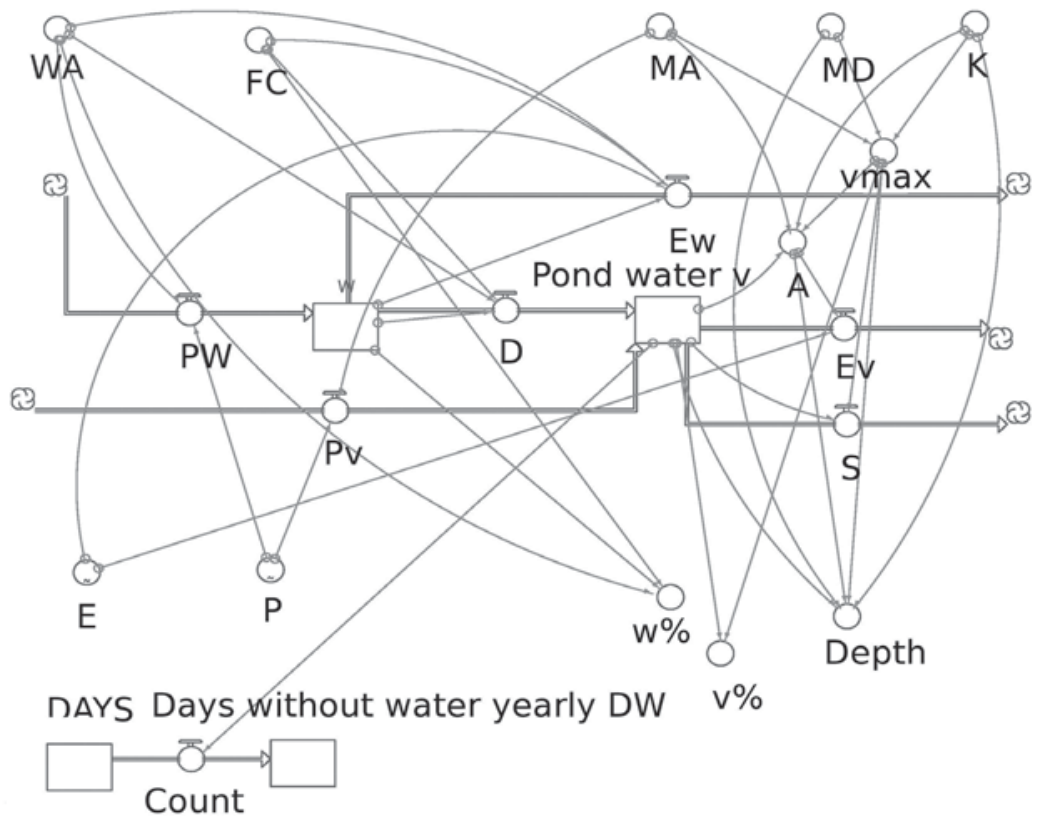

b)

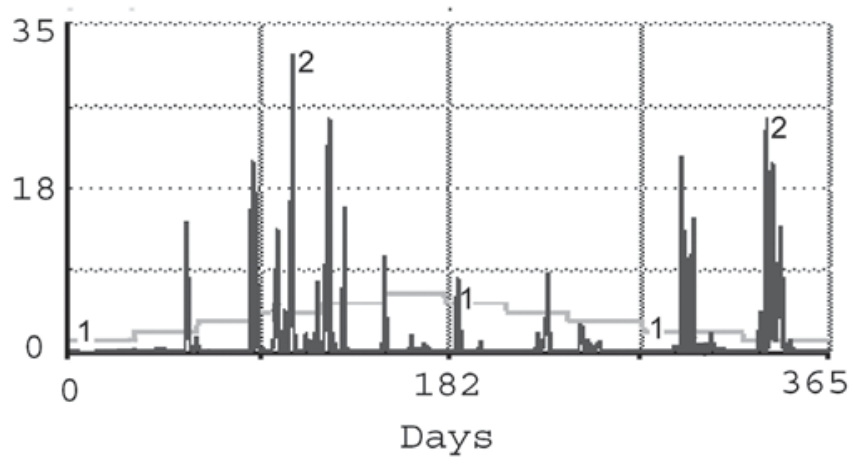

c)

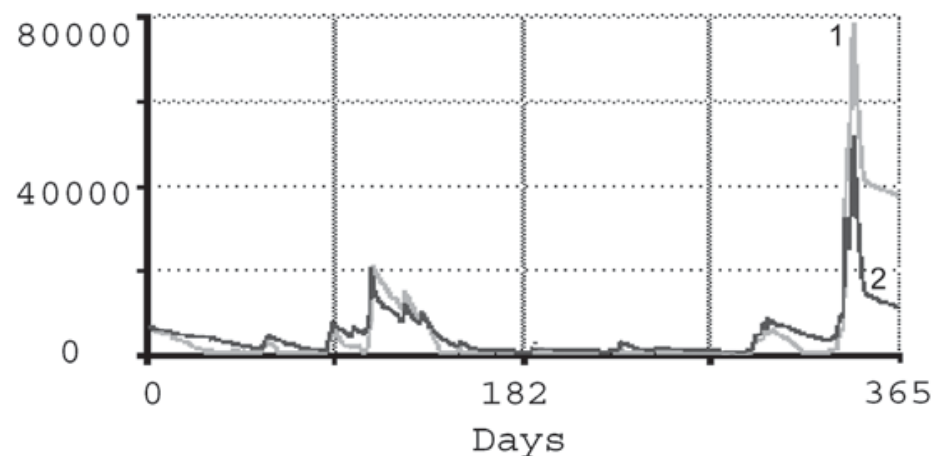

Figure 1. Pond hydrology simulation model, illustrating: a) STELLA model diagram, b) daily evolution of precipitation and evapotranspiration for 2005 (evapotranspiration is the daily average from monthly data): evapotranspiration pattern (1), rain pattern (2) and c) amount of water $\left(\mathrm{m}^{3}\right)$ in the simulated ponds: cylindrical pond (1) and conical pond (2). Modelo de simulación de la hidrología de una charca, ilustrando: a) el diagrama del modelo en STELLA, b) la evolución diaria de la precipitación y la evapotranspiración $\left(\mathrm{l} / \mathrm{m}^{2}\right)$ para 2005 (la evapotranapiración es la media diaria extraída de datos mensuales, $l / \mathrm{m}^{2}$ ): patrón de evapotranspiración (1), patrón de lluvia (2) y c) cantidad de agua $\left(\mathrm{m}^{3}\right)$ en las charcas simuladas: 1) charca cilíndrica y 2) charca cónica. 
(m); and $K$, shape coefficient. $K$ represents the relationship between pond volume and the volume of a cylinder and is estimated for each pond as:

$$
K=\frac{v_{\max }}{M A \times M D}
$$

where $v_{\max }$ is the water volume in the pond when it is at maximum. Therefore, $K=1$ for a cylindrical pond, and $K=1 / 3$ for a conical pond.

Input water in the pond depends on $P_{v}(t)$ and $D(t)$, and output on $E_{v}(t)$ and $S(t)$ :

$$
\begin{aligned}
P_{v}(t) & =P(t) \times M A \\
E_{v}(t) & =E(t) \times A(t) \\
S(t) & =o, \quad \text { if } \quad v \leq v_{\max }, \quad \text { and } \\
S(t) & =v-v_{\max }, \quad \text { if } \quad v>v_{\max }
\end{aligned}
$$

therefore, surface overflow is fast enough to be done in one day. It is not representing any narrow channel, but a wide enough one.

\section{Simulation methods}

Simulations were performed using STELLA 8.0, a high-level simulation language (STELLA(C) 2003, http://www.hps-inc.com). To date, a number of ecological models with wetland hydrology has been developed using this software (for example, Zhang \& Mitsch 2005). Modelling of the temporary ponds dynamics allows to predict the water dynamics for different ponds shapes and sizes, and to compare the predicted values with the real ones. Figure 1 shows the model and its application to two different pond shapes: cylindrical and conical.

\section{RESULTS AND DISCUSSION}

\section{Sensitivity analysis}

For the sensitivity analysis of the model we used a typical pond $\left(W A=5000 \mathrm{~m}^{2} ; F C=501 / \mathrm{m}^{2} ; M A\right.$ $=200 \mathrm{~m}^{2} ; M D=20 \mathrm{~cm}$ ) with real meteorological data from Tortosa, Spain, on 2005, extracted from National Meteorology Institute of Spain. At this point, small differences are not so important be- cause the objective is to see how sensitive the state variables ( $W$ and $v$ ) are, to changes in the parameters of the pond and the watershed. For these analyses the model has been run with a change in the parameter of $\pm 50 \%$ the actual value.

Analysis to test the effect of the pond shape $(K)$ has also been made by modelling a high rainfall and a drought period afterwards, to see the drying dynamics and to measure how many days without rainfall each pond will persist. This information on the optimal shape of ponds is extremely important for managers who are actively involved in new pond creation.

The most important parameters for the water dynamics of the pond are the maximum depth of the pond and its shape. Changes produced in the number of days with water, the amount of water in the pond and its depth, are very clear. On the other hand changes on the watershed area, and the pond area did not change the water dynamics of the pond. The dynamics of the amount of water in the soil of the watershed is significantly affected by the saturated water content, and therefore this parameter also affects the water dynamics of the pond. Surprisingly, it did not affect the number of days the pond is dry (Table 1).

Table 1. Sensitivity of the state variables (soil water, $\mathrm{W}$ and pond water, v) to changes on the pond and watershed parameters $( \pm 50 \%)$. "No" means no significant changes and "Yes" significant changes on the dynamics, either with the lesser or the upper parameter value, or both. W: soil water; v: pond water; WA: Watershed area; FC: Saturated water content of the watershed soil; MA: Maximum area of the pond; MD: Maximum depth of the pond; K: Shape coefficient of the pond. Sensibilidad de las variables de estado a los cambios en los parámetros de la charca y de su cuenca de captación ( $\pm 50 \%$ ). "No" significa que no hay cambios significativos y "Yes" significa que hay cambios significativos en su dinámica, tanto con los valores más altos o más bajos del parámetro, como con ambos. W: agua en el suelo; v: agua en la charca; WA: Área de la cuenca de captación; FC: Contenido de agua a saturación del suelo de la cuenca de captación; MA: Área máxima de la charca; MD: Profundidad máxima de la charca; $K$ : Coeficiente de forma de la charca.

\begin{tabular}{|l|ccccc|}
\hline & \multicolumn{5}{|c|}{ Sensibility $\pm 50 \%$} \\
& $W A$ & $F C$ & $M A$ & $M D$ & $K$ \\
\hline Days without water & No & No & No & Yes & Yes \\
$\% W$ & No & Yes & No & No & No \\
$\% V$ & No & Yes & No & Yes & Yes \\
Depth & No & Yes & No & Yes & Yes \\
\hline
\end{tabular}


The watershed area is not important in this case, because saturated water content is relatively high and therefore it is necessary for a really heavy rainfall to produce overflow. When $F C$ is reduced, overflow is produced for two rainfall periods in which the pond gets totally full. The combined effect of watershed area and $F C$ is not very strong, because under a heavy rainfall, the pond will be filled (or almost filled) anyway. If the saturated water content is very low, and watershed area very high, what occurs is that for almost every rainfall event, the pond will be totally filled. This is not very important in the Mediterranean climate area, where rain is not very frequent, but when it occurs it is usually strong enough to fill all the ponds, even the ones with very small watershed areas.

The maximum area of the pond is not important in the prediction of the number of days with or without water, mainly because water dynamics depend mainly on depth. An increase of the volume of water due to surface increase will not change the water dynamic because the main input and output processes are area dependent: precipitation and evaporation.

Therefore, it can be said that a deep pond (independently of other parameters) is going to last more that a shallow one, but also the shape is very important.

\section{Effect of the shape}

This effect is general and follows a lineal relationship with $K$ (Fig. 2), but this effect also is de-

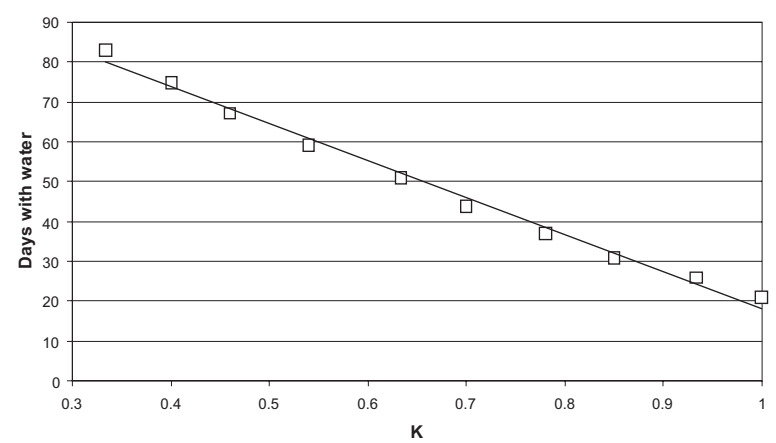

Figure 2. Linear relationship between $\mathrm{K}$ and the number of days with water in the simulated pond, for weather at Tortosa in 2005. Relación lineal entre $K$ y el número de días con agua en la charca simulada, para el tiempo atmosférico de Tortosa en 2005.

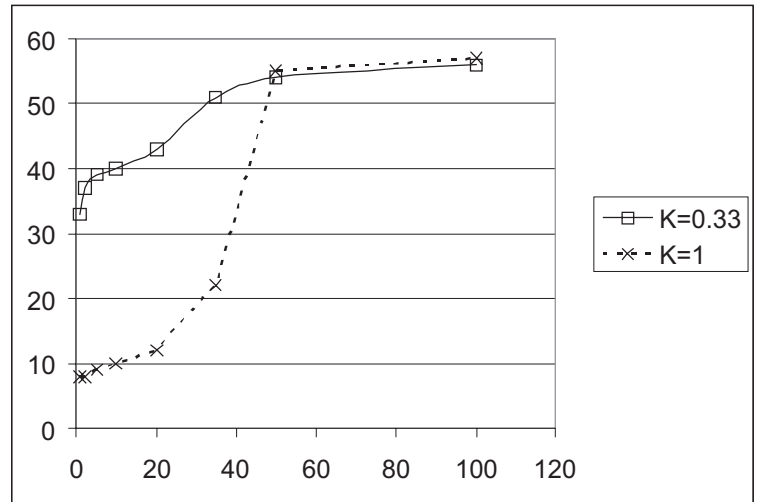

Figure 3. Days with water in two ponds with different shapes (cylindrical vs. conical) after rainfall of different intensities. Días con agua en dos charcas con diferente forma (cilíndrica vs. cónica) después de periodos de lluvia de diferente intensidad.

pendent on the amount of rain for each rainfall episode. The effect of $K$ is most important for light rainfall episodes than for heavy rainfall episodes (Fig. 3). Cylindrical ponds dry faster than conical, and this effect is more evident after a shallow rain episode. This occurs because when a conic pond is drying, the actual area of the pond and therefore, its evaporation, diminishes. A cylindrical pond has the same area (and high evaporation) even with little water.

\section{CONCLUSIONS}

This study has investigated hydrological processes of Mediterranean temporary ponds in eastern Spain through a simulation model. Sensitivity analysis of state variables to changes on the pond parameters were developed for small and shallow Mediterranean ponds in order to understand the effect of pond size and shape on their hydroperiod.

This model can be of great help to manage the hydroperiod of newly made ponds or to direct the restoration of existing ponds, though it will need to be calibrated and validated for each particular pond.

From the results of this study, there are some predictions that should be taken into account for the creation of new ponds in order to control their hydroperiod:

i) Watershed area of the pond will only be important for low intensity rain regimes and 
for soils with very low saturated water content. If the soil absorbs most of the water or, on the other hand, each rainfall episode totally fills the pond, then the watershed area should be of little importance for the pond hydroregime. Only for intermediate cases should it be of some importance.

ii) Depth and shape are the most important parameters to control the pond hydroperiod.

iii) Deeper ponds will dry more slowly (and therefore have more days with water during the year and shorter drought periods) than shallower ones, independently from their area and from the total amount of water. This will only be the case if the water output is through evaporation only.

iv) Conical ponds fill more deeply for the same amount of rain than cylindrical ponds (same depth and area). Therefore a conical pond should have more days with water for the same amount of rain, unless the pond does get totally full in each rainfall episode. If every rainfall episode is heavy enough to totally fill the pond, then there should be no difference between the conical and cylindrical ponds hydroperiods.

\section{ACKNOWLEDGEMENTS}

We are indebted to Vicente Sancho and Ignacio Lacomba for their suggestive comments. We also thank Juan Jiménez for his assistance along this study. Acknowledgements are also given to the Environmental Council of Generalitat Valenciana (Spain). This work was funded by UE and GVA (LIFE05/NAT/E/000060).

\section{REFERENCES}

BEJA, P. \& R. ALCAZAR. 2003. Conservation of Mediterranean temporary ponds and agricultural intensification: an evaluation using amphibians. Biological Conservation, 114: 317-326.

BLISS, S. \& P. ZEDLER. 1998. The germination process in vernal pools: sensitivity to environmen- tal conditions and effects on community structure. Oecologia, 113: 67-73.

BOHONAK A. \& H. WHITEMAN. 1999. Dispersal of the fairy shrimp Branchinecta coloradensis (Anostraca): effects of hydroperiod and salamanders. Limnol. Oceanogr., 44(3): 487-493.

BROOKS, R. 2000. Annual and seasonal variation and the effects of hydroperiod on benthic macroinvertebrates of seasonal forest ("vernal") ponds in central Massachusetts, USA. Wetlands, 20(4): 707 715.

CROWE, E., A. BUSACCA, J. REGANOLD \& B. ZAMORA. 1994. Vegetation zones and soil characteristics in vernal pools in the channelled scabland of Eastern Washington. Great Basin Nat., 54(3): 234-247.

GALLAGHER, S. 1993. Life-history variation in the temporary pool snail, Fossaria-sonomaensis, in the northern Sacramento Valley. Am. Midland Nat., 130 (2): 372-385.

HOULAHAN, J. E., C. S. FINDLAY, B. R. SCHMIDT, A. H. MEYER \& S. L. KUZMIN. 2000. Quantitative evidence for global amphibian population declines. Nature, 404: 752-755.

KEELEY, J. \& P. ZEDLER. 1998. The global distribution of vernal pool ecosystems. In: Ecology, Conservation, and Management of Vernal Pool Ecosystems. Bauder, E., Belk, D., Ferren Jr., W., Ornduff, R. (eds.):1-14. California Native Plant Society, Sacramento, CA.

KING, J., M. SIMOVICH \& R. BRUSCA. 1996. Species richness, endemism and ecology of crustacean assemblages in northern California vernal pools. Hydrobiologia, 328(2): 85-116.

MARCUS, V. \& S. WEEKS. 1997. The effects of pond duration on the life history traits of an emphemeral pond crustacean, Eulimnadia texana. Hydrobiologia, 359: 213-221.

MITSCH, W. J. \& J. G. GOSSELINK. 2000. Wetlands. John Wiley \& Sons, New York. 920 pp.

MOREY, S. 1998. Pool duration influences age and body mass at metamorphosis in the WesternSpadefoot toad: implications for vernal pool conservation. In: Ecological, Conservation, and Management of Vernal Pool Ecosystems, C. Witham, E. Bauder, D. Belk, W. Ferren Jr., R, Ornduff, R. (eds.).: 86-91. California Native Plant Society, Sacramento.

PYKE, C. R. 2004. Simulating vernal pool hydrologic regimes for two locations in California, USA. Ecological Modelling, 173: 109-27. 
SIMOVICH, M. \& S. HATHAWAY. 1997. Diversified bet-hedging as a reproductive strategy of some ephemeral pool anostracans (Branchiopoda). $J$. Crustacean Biol., 17(1): 38-44.

SNODGRASS, J., J. ACKERMAN, A. BRYAN \& J. BURGER. 1999. Influence of hydroperiod, isolation, and heterospecifics on the distribution of aquatic salamander (siren and amphiuma) among depression wetlands. Copeia, 17(1): 107-113.

STAMATI, F., N. NIKOLAIDIS, E. DIMITRIOU, N. SKOULIKIDIS \& T. KOUSSOURIS. 2008.
Hydro-geochemical aspects of a typical Mediterranean temporary ponds in western Crete (OmalosPlateau). Journal Environ. Qual., 37: 164-173.

WILLIAMS, P., M. WHITFIELD \& J. BIGGS. 2008. How can we make new ponds biodiverse?. A case study monitored over 7 years. Hidrobiologia, 597: 137-148.

ZHANG, L. \& W. J. MITSCH. 2005. Modelling hydrological processes in created freshwater wetlands: an integrated system approach. Environmental Modelling \& Software, 20: 935-946. 